\title{
小幡篤次郎・甚三郎『英文熟語集』と ウェブストル氏字典
}

竹 中 龍 範

0.はじめに

わが国初の英語熟語辞典として小幡篤次郎・甚三郎『英文熟語集』が刊行されたの は明治改元も間近い慶応四戊辰年三月のことであった。その規模・内容からして辞書 と呼ぶには不完全なものという見方もあろうが1), 先行辞書との関わり, 後続辞書一 の影響2)という点から見て, 本邦英語辞書発達史のうえで重要な milestone であるこ とは何人も否定しえないところであろう。

この意義を認めて, 昨春, 家蔵の同書を原本として復刻版を出版し,「解題」を付し たのであるが，その「解題」中の記述に対し，疑義を呈された方があった。それは「序 にある「ウェブストル」氏字典がどれをさすのか不明であるが，筆者家蔵のWebster， Noah An American Dictionary of the English Language.(G.\& C. Merriam, 1864; ただし1871年版によった）の各語の終わりについている熟語の解説と『英文熟語集』 の熟語とが一致しているものが多いので，この版によったものかとも思われる。とい う点に対し，小幡兄弟が利用したのは1847年版ではないのか，というものであった。 そこでこれについて再調查をしたので，ここにその結果を報告したい。

\section{1.『英文熟語集』とその先行辞軎}

小幡兄弟が『英文熟語集』を編纂する上で参照したものとして，『英和対訳袖珍辞 書』,「ウェブストル」氏字典, 華英字類 ${ }^{3)}$ がその「序」に明記されている。ただし， 『英和対訳袖珍辞書』については，「序」に「世字典二欠乏ス[0]英和対訳袖珍辞書ナル モノ八世人,能ク知ル所ニシテ初学必要,書ナリ[0]此习除ク/外八絶テ捜字二供スル モノナケレバ(後略)」と述べられているのみで, 利用した旨は記されていないが，そ の利用の形跡は「解題」に明らかにした通りである。 


\section{英 学 史 研究 第 16 号}

さて, そこで, 問題の「ウェブストル」氏字典であるが, ウェブスターのAn Amer ican Dictionary of the English Language. は1828年に出され4), ウェブスター自身 の手による改訂版が1840年に出版されている。そして, 彼の死後, 出版権はメリアム 社に買い取られ，1847年には Chauncey A. Goodrichによる改訂版が世に送られる。 1859年には pictorial supplement が加えられ，1864年には，以後 “Unabridged” と呼ばれた改訂版が Noah Porter 編集の下に出版され，1879年の増補を経て，1890年 のWebster's International Dictionary. 刊行まで利用されることになる5)。

では,このうちどの版を小幡兄弟が利用し得たかということになるが，『英文熟語 集』の出版年(1868)からみて，1864年の版，ないし，それ以前の版ということになる。 しかし，1828年の初版まで遡る必要もない。というのは，「日本にもたらされたもので は恐らく一番古い刊本と考えられる」福井県立大野高等学校蔵のウェブスター辞典が 1852年刊であること（但し，この版の出版社はHarper \& Brothersである)，「いわ ゆる大辞典と称される本来のウェブスター辞典としては, 今のところ泉丘本よりも古 いものは発見されていないよう」7)であるという金沢泉丘高等学校所蔵のものが1859 年刊の㨀図入り非省略版であること，などを考え併せれば，検討の対象となり得るの は1847年版，1859年版，1864年版に限定されるからである。さらに，この3つの版に 関しても, Webster's New International Dictionary of the English Language, edited by W. T. Harris. (G. \& C. Merriam, 1917) の序文にある “After the death of Noah Webster, a new edition of the Dictionary appeared in 1847 under the editorship of his so-in-law Professor Chauncey A. Goodrich, the original two volumes being brought into one. A pictorial supplement was added in 1859.

A general revision, which became popularly known as the "Unabridged," was published in 1864. Of this edition Dr. Noah Porter, later President of Yale College, was editor in chief;....” という記述から判断して, 辞書本体の内容そのも のについては1847年版と1864年版との比較ということになろう。ただし，今回の調査 では，資料上の制約から1859年版と1864年版の比較という形をとった。

\section{2. ウェブストル氏字典利用の形跡}

ここで，「解題」で，利用したウェブストル氏字典は1864年であろうとした点につ いて,「解題」では充分な根拠を示すことができなかったので, 具体的に示すことに 
する。

ウェブストル氏字典の「各語の終わりについている熟語の解説と『英文熟語集』の 熟語とが一致しているものが多い」という点について,「Affair: an__of honor. 二人差向／闘」「Affiliat [sic.]：__ed socities[sic.]. 相扶助スル仲間」「Impression: proof_..挍合摺リ版」の3つについて，ウェブストル氏字典1864年版からそれ ぞれ見出し語ごとに例を示す。

Af.fâin' (4), in. [Fr. affaire, f., O. Fr. m., Pr. afiır, afaire, m., It. affire, m., from ad, $a$, and Fr. ficire, Pr. fur, fuire, It. fare, Lat. facere, to make, do. See ADo.]

1. That which is done or is to be done; as, a difficult cificir to manage; hence, business of any kind, especially public business. "At the head of affairs." Junius. "A talent for affairs." Prescott.

2. (Mil.) An engagement of troops, usually partial or of minor inportance. "The disgraceful ciffair at Seron."

3. Action; endeavor. [Obs.]

And with his best affair Obeyed the pleasure of the Sun. An affair of honor, a duel.

sipenser.

Chapman.

Af-rill-äte, $v . t$. [imp. \& p.p. AFFILIATED; p.pr. \& vb.n. AFFILIATING.]

[L. Lat. adfiliure, "iffiliure, to adopt as son, from Lat. $a d$ and filius, son; Pr. afilhar, Fr. affilier, O. Sp. "fijnr, N. \$p. "ihijur.]

1. To adopt; to receive into a family as a son; hence, to receive into fellowship; to ally.

Is the soul affiliated to God, or is it estranged and in rebellion?

I. Taylor.

2. To receive into a society as a member, and initiate into its mysteries, plans, \&c.

Affiliated. societies, local auxiliary societies, connected with a central society, or with each other. 
Im-prës'sion (-prěsh'un), $n$. [Fr. impression, Sp. impresion, It. impressione, Pr. entpressio, Lat. inpressio.]

1. The act of impressing or stamping; marking by pressure or imprint; the communiention of a stamp, mold, or character, by external force.

2. That which is produced by pressure; $-\mathbf{a s},(a$. A stamp made by pressure; mark; indentation, as an impression on wax, Sic. (b.) Sensible result of an influence exerted from without: effect of an attack made, a power caused to operate, an affecting agency exerted, or the like.

To shelter us from impressions of weather, we must spin, we must weave, we must build. Barrovo. (c.) Influence on the purposes, feelings, or actions; hence, sometimes, love, interest, concern.

His words inepression left.

Millon.

I have a futher's dear impression

And wish, before I fall into my grave,

That I might see her married.

Ford.

(d.) Effect or influence on the organs of sense, which is the condition of sensation or sensible perception; the object as perceived and remembered; hence. an indistinct notion, remembrance, or belief. (e.) $\mathbf{A}$ copy taken by pressure from type, from an engraved plate, or the like; hence, also, all the copies of a work taken at once; an edition.

For ten impressions which his books have had in 80 many yeurs, at present a hundred books are scarcely purchased in a twelvemonth.

Dryolen.

3. That which impresses, or exercises an effect, action, or agency. "The portentous blaze of comets and impressions in the air." Mrilton. "A fiery impression falling from out of heaven to earth." Holland.

4. Impressiveness; emphasis. [Obs.]

Which must be read with an impression, and anderatood limitedly. Jfiltor.

5. (Paint.) (a.) The ground-color, or that which is first laid on to receive the other colors. (b.) A stratum of a single color laid upon a wall or surface for ornament, upon outside work, or upon metals to protect from humidity.

Proof impression (Print.), an early impression taken, as trom types, an engraved plate, lithographic stone, and the like. See Proof. 
ウェブストル氏字典の利用は殆どがこの形式をとり，定義中に出る熟語の採択の例 はごく僅かしかない。

つぎに，ウェブストル氏字典をどの程度利用しているかを見るために，AとIの部 分について, ウェブストル氏字典中の定義と対比してみよう。ここに挙げたものの外 にも，恐らくこれは採っているだろうと思われるものもあるが（例：After：

birth; most ; thought.), 不確定な要素が残っているので, それらは取り 上げていない。

1. Acquies $[\mathrm{c}] \mathrm{e}$ : in. 十分スル，従属スル Acquiesced in, in a passive sense, compiled with; submitted to, without opposition; as a measure has been acquiesced in.

2. Act: to up to.

同様ノ働スル，十分スル To act up to, to equal in action; to fulfill; as he has acted up to his engagement or his advance.

3. Affair: an of honor. An affair of honor, a duel.

4. Affiliat $[\mathrm{e}]$ : ed soci $[\mathrm{e}]$ ties. Affiliated societies, local auxiliary societies, connected with a central society, or with each other.

5. Again: and

Again and again, often; with frequent repetition.

6. $" \prime$ : to and アチラコチラヘ

To and again, to and fro. [Obs.]

7. Aim: to cry 勢付ケル To cry aim, to encourage. [Obs.]

8. Air: to take 公ニスル、広メル，知ラセル To take air, to be devulged; to be made public.

9. " : to take the 野外二行ク, 散歩スル, 乗廻ル To take the air, to go abroad; to walk or ride out.

10. All: in ナニモカモ All in all, a phrase which signifies all things to a person, or every thing 


$$
\text { 英学史研究第16号 }
$$

desired.

11. " : and some.

All and some, one and all. [Obs.]

12. " : : hollow.

All hollow, entirely, completely; as, to beat any one all hollow. [Colloq.]

13. Alone : to let

其儘指置ク

To let alone, to suffer to rest ; to forbear molesting or meddling with; to suffer to remain in its present state.

14. Along : all

全キ道，全キ隔，全キ長サ，絶へス，始終 All along, the whole way, distance, or length; - prostrate.

15. $\prime$ : of. $\cdots$ 二帰イテ，ㄱ.訳ニテ Along of, denotes owing to, or on account of ; as in Shakespeare, when the mayor was willing to have the troops come in, "so 'twere not 'long of him;" i. e., not owing to his leave. So too in the London Punch, "This increase of price is all along of the foreigners."

16. " : shore.

海岸二沿テ

Along shore, by the shore or coast; length-wise, and near the shore.

17. $\prime$ : side.

並テ

Along-side (Naut.), side by side.

18. Anchor : to cast

錨ヨ拋ル

To cast anchor, or to anchor, to let go an anchor to keep a ship at rest.

19. " : to weigh

錨Э起ス

To weigh anchor, to heave or raise the anchor out of the ground.

20. Anvile[ sic. ]: [sic.] to be on the 詮議スル，用意スル

To be on the anvil, to be in a state of discussion, formation, or preparation, as when a scheme or measure is forming, but not matured.

21. Apple : of eye.

瞳子

Apple of the eye, the pupil.

22. $\prime \prime$ : of discord.

争論/趣意, 恨/趣意 Apple of discord, a subject of contention and envy, so called from the 


\section{小幡篤炊郎・甚三郎『英文熟語集』とウェブストル氏字典}

golden apple on which was written "For the fairest," and which was thrown into an assembly of the gods by Eris, the goddess of discord. It was contended for by Juno, Minerva, and Venus, and was adjudged to the latter.

23. " : : pie order. 十分ナル順序

Apple-pie order, perfect order or arrangement.

24. Arms : to be in 戦ノ用意スル

To be in arms, to be in a state of hostility, or of preparation for war.

25. " : : to be under 軍装スル

To be under arms, to be armed and in readiness for fighting.

26. " : to work at 's length.

労シテ功ナシ

To work at arm' length, to work awkwardly or disadvantageously.

[Entered under the heading of ARM, $\underline{n}$.]

27. Aside : to set

廃スル，萧テル

To set aside (Law), to annul or defeat the effect or operation of, by a subsequent decision of the same or of a superior tribunal; as, to set side a verdict or a judgement.

28. Assign : to dower.

塞婦ノ取前 7 定メル

To assign dower, to set out by metes and bounds the widow's share or portion in an estate.

29. Ice : to break

企ヨ起ス, 初度/難

To break the ice, to make the first opening to any attempt; to remove the first obstructions or difficulties; to open the way.

30. Impose : to on.

欺ク

To impose on, to pass or put a trick or deceit on.

31. Impression : proof 挍合摺り版，

Proof impression (Print.), an early impression taken, as from types, an engraved plate, lithographic stone, and the like.

32. In : that. $\cdots$ 故デ，‥訳デ

In that, because; for the reason that. 
33. " : the name of.

In the name of, in behalf of; on the part of; by authority; as, it was done in the name of the people; -often used in invocation, swearing, praying, and the like.

34. Incidence : angle of

落角 Angle of incidence, the angle which a ray of light, or the line of incidence of a body, falling on any surface, makes with a perpendicular to that surface; also formerly the complement of this angle.

35. $"$ : line of

落線

Line of incidence, the line in the direction of which a surface is struck by a body, ray of light, and the like.

36. Incisive : teeth.

前歯

Incisive teeth, fore teeth, the cutters or incisors.

37. Inclined : plane.

斜面

Inclined plane (Mech.), a plane that makes an oblique angle with the plane of horizon; a sloping plane. It is one of the mechanical powers.

38. Index : finger.

人指シ指

Index finger, the fore finger of the hand; - so called from its use in pointing out.

39. " : hand.

時計ノ針

Index hand, the pointer or hand of a clock, watch, or other registering machine; a hand that points something.

40. Influential : characters.

人望ヨ得タル人 Influential characters, persons who possess the power of inclining or controlling the minds of others.

41. Inform : to against.

訴ヘル To inform against, to communicate facts by way of accusation against ; to give intelligence of a breach of law by; as, two persons came to the magistrate, and informed against it. 
42. Inheritable : blood.

血統，相続スヘキ

Inheritable blood, blood or relationship by which a person becomes qualified to be an heir, or to transmit possessions by inheritance.

43. Intent : to all and purpose [sic.].

実二, 実用二，全ク

To all intents and purposes, in all applications or senses; practically; really.

44. Iron : cast

鋳鉄

Cast iron, or pig iron, a compound of carbon and iron, obtained as a direct produt from the act of smelting iron ore in the blast furnace. It is harder than pure iron, is more or less brittle, is fusible, and granularcrystalline in structure; and in different varieties has a white or grayish color. Its fusibility is mainly due to the carbon it contains.

45. " : wrought

鍛鉄

Wrought iron, the purest form of iron known in the arts. It is soft, very tenacious, and at a high temperature may be welded. It possesses great malleability and ductility. When beaten into bars, it is known as bar iron or merchant-bars. It has a bluish-gray color, and always contains some carbon.

以上の例からも明らかなように, ウェブストル氏字典への依存度はかなり大きく， I の項などは収録熟語数 28 のち，17にものぼる数のものをウェブストル氏字典から 採っている。もちろん, ウェブストル氏字典で「廃用」とされているものを採ったり

(例：to and again, to cry aim, etc.), 解釈が不充分であったり (例：affiliated societies）するものも含まれているが，ウェブストル氏字典への依存は大いなるもの がある。

\section{3. ウェブストル氏字典の版について}

それでは，今回の調査の眼目であるウェブストル氏字典の版について検討すること にする。

既に述べたように，ウェブストル氏字典は1859年版と 1864年版とを比較した。1859 年版については名古屋大学附属図書館蔵 Webster, Noah An American Dictionary 
of the English Language, Revised and Englarged by Chauncey A. Goodrich. Pictorial Illustrations added. (Philadelphia: J. B. Lippincott \& Co., Publishers, 1860）を調査資料とした ${ }^{8)}$ 。出版社は Merriam 社ではないが, Burkett（1979）の調査 に見られるように, ウェブスター辞典とLippincott 社との関係は緊密で,このLippin$\operatorname{cott}$ 版は調査資料とするに足るものと判断し，比較検討する材料とした。これと家 蔵の1864年版とを比べたのであるが，全ての熟語について見るのは尣慢に過ぎるので，

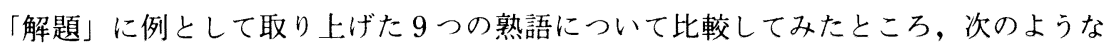
結果を得た。1864年版と1859年版とを対比して示す。

\section{[1864 Edition]}

Age; 一 of consent. 婚姻スヘキ龄男十六才

‘ Age of consent to marriage is fourteen in males, and twelve in females.]

Bell; to-the cat. 猫二鈴 7 付ル、勢ヨ減スルト云彥

[To bell the cat, to put a bell on, to encounter and cripple one of a greatly superior force; - a phrase derived from the fable of the mice resolving to put a bell on the cat, to guard them against his attack.]

Experience; to-religion. 耶䔡教二変スル

(To experience religion (Theol.), to become a convert to the doctrines of Christianity; to experience the truth of the great doctrines of divine grace.]

Flesh; an arm of -. 援兵

[An arm of flesh, human strength or aid.] Fool; -'s errand. 患ナル企

[Fool's errand, an absurd or fruitless search or enterprise; the pursuit of what can not be found; the undertaking what is im-

[1859 Edition]

硋 当な

To bell the cat, to encounter and cripple one of a greatly superior force. The phrase is derived from the fable of the mice resolving to put a bell on the cat, to guard them against his attack.

該 当なし

An arm of flesh; human strength or aid.

該当なし

但し，見出し上し下登録

FOOL'S-ER'RAND, n. The pur. suit of what cannot be found. 
portant.]

Hand; putting the-under thigh. 誓つ克昔/礼 7

`Putting the hand under the thigh, an ancient ceremony used in swearing.]

Lot; to pay scot and-. 分二応シテ税

(To pay scot and lot, to pay taxes according to ability.]

Ordinary; $\mathrm{ph}[\mathrm{y}]$ sician of - 待医

In ordinary, in actual and constant service; statedly attending and serving; as, a physician or chaplain in ordinary.]

" ; - seamen. 未熟

[Ordinary seaman(Naut.), one not expert or fully skilled, and hence ranking below a seaman.]

Putting the hand under the thigh, was an ancient ceremony used in swearing

該 当な

In ordinary; in actual and constant service; statedly attending and serving; as, a physician or chaplain in ordinary. An ambassador in ordinary, is one constantly resident at a foreign court.

An ordinary seaman is one not expert of fully skilled, and hence ranking below a seaman. (Def. 6 of OR' DI-NA-RY, a.]

この対比から見てわかるように，『英文熟語集』の「序」に挙げられている「ウェ ブストル」氏字典は1864年の版を指している。その根拠として挙げられる点は,

（1） 1864年版にはあるが，1859年版には該当する熟語が見当らない場合があること。

（2） 1864 年版では見出し語の定義等の後に熟語が載せられているのに，1859年版で は独立の見出しとなっていたり（例：fool's errand），定義中に熟語が現われたり

(例 : ordinary seaman) していること。

ということである。また，1859年版の方で「該当なし」としたものについて，例えば age of consent はageの項, consent の項, いずれにおいてもそのような熟語は見当 らないし，1864年版では『英文熟語集』の見出しとなっている語をひけば，必ずその 定義等の後に求める熟語が掲載されているという原則からして, age of consentを得 るために consent をひくというのは原則に反する，無用の操作である。

したがって，『英文熟語集』編纂の際に小幡兄弟が参照した「ウェブストル」氏字 典は Webster, Noah An American Dictionary of the English Language. Thoroughly Revised, and Greatly Enlarged and Improved, by Chauncey A. Goodrich, D. D., and Noah Porter, D. D. (Springfield, Mass.: Published by G. \& C. Merri- 


\section{英 学 史 研 究 第 16 号}

am，1864）であると結論することができよう。当時の状況からして、1864年出版の辞 書を輸入し，それを参照して，1868年春には『英文熟語集』を出版するということは 困難なことではあったろうが，これだけの証左を得ては，それが事実であるという ことは認めざるを得ないであろう。

\section{4.おわりに}

このように「ウェブストル」氏字典の版を確定しても, それが果たして, 所謂大辞 典の方なのか，それとも簡略版なのか，という疑問は完全に拭えた訳ではない。また， 当時わが国に将来されていたウェブストル氏字典の数は僅かであったろうと思われる が，小幡兄弟が利用したものはどこの蔵書であったのかというような問題も残されて いる。『英文熟語集』を巡る諸辞書の関わりなどの問題などとともに，今後の調査・ 研究の課題としたい。

\section{〔注〕}

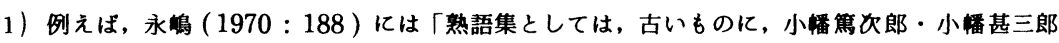
共編『英文熟語集』(慶応 4 年(1868)) があろが，てれはまだその名に価しない程度の簡略な、 ちのである。と評価されている。

2)との点について,「解題」に明らかにした内田晋斎編『浅解英和辞林』(明治 4 年) および, 美国平文先生編訳『和英語林集成』再版 (明治 5 年) のほかに, 大屋愷敛 ほ加編『広益英倭字 典』(明治 7 年, 金沢)にも『英文熟語集』の影響が及んでいるととを本学会北陸支部長今井一良 先生から御教示頂いた。御厚意に対し篤く御礼申し上げる。

3）との華英字類を『大阪女子大学蔵日本英学資料解題』では恐らくLobscheidのものであ ろうとしていろが, 著者はてれに疑問を覚える。というのは, W. Lobscheid English and Chinese Dictionary, 4 vols. は 1866 年から 1869 年にかけて香港で出版されており, 小幡兄弟が利用したとしてもせいぜい第 1 巻(1866)，第 2 巻(1867)くらいだと思われろからで ある。これについては機会を改めて調査したいと思っている。

4) ウェブスターの辞書はこの An American Dictionary の前に A Compendious 
小䊩篤次郎・甚三郎『英文熟語集』とウェブストル氏字典

Dictionary of the English Language. が1806年に出されているが，てれはててに 扱う問題とは直接関係しないので触れない。

5) Harris, W.T. (ed.) Webster's New International Dictionary of the English Language. (G. \& C. Merriam Co., 1909; 1917 printing) の序文に拠 った。

6) 福井県立大野高等学校『大野藩等旧蔵図書目録』(昭和 55 年)

7) 今井一良「金沢所在古版ウエプスター辞書について」『石川郷土史学会々誌』第 13 号。

8)との調查に便宜を与えられた名古屋大学附属図書館の方々に御礼を申し上げる。

\section{参考文献}

大阪女子大学附属図書館編 (1962)『大阪女子大学藏 日本英学資料解題』(大阪女子大学)

竹中龍範 (1982)「『英文熟語集』解題」同書復刻版附録 ( あき書房)

豊田実 (1939) 『日本英学史の研究』(岩波書店)

永鳰大典 (1970)『刑和・英和辞書発達史』( 講談社)

—(1974) 『英米の辞書一歴史と現状一』(研究社)

町田陖昭 (1981) 『三代の辞書 英和・和英辞書百年小史』改訂版 (三省堂)

Burkett, Eva Mae (1979) American Dictionaries of the English Language

Before 1861. (The Scarecrow Press, Inc.)

\section{Obata Brothers' English Idioms}

and Webster's Dictionary.

In 1868, English Idioms, the first dictionary of English idioms in Japan, was published. Though the editors, Tokujiro Obata and Jinzaburo Obata, mentioned in its preface the dictionaries that they used in the compilation of English Idioms, they did not specify the edition of Webster's dictionary. In this paper, the author compared the 1859 edition and the 1864 edition of Webster's Unabridged Dictionaries, and drew a conclusion that it is the 1864 edition that Obata brothers used to compile their dictionary. 